\title{
Establishing Good Corporate Governance in Overcoming the Dualism of State Owned Enterprises Sectoral
}

\author{
Tuhana $^{1}$, Jamal Wiwoho ${ }^{2}$, I Gusti Ayu Ketut Rachmi Handayani ${ }^{3}$ \\ ${ }^{1.2 .3}$ Universitas Sebelas Maret \\ Surakarta, Indonesia \\ dosentuhana@gmail.com
}

\begin{abstract}
This study was done to answers 2 (two) research problems: (i) why is it necessary to establish good corporate governance in overcoming the sectoral dualism of BUMN/SOEs; and (ii) how the BUMN/SOEs based on good corporate governance are able to optimize the management of natural resources in a professional manner. BUMN (State Owned Enterprises/SOEs) is a public company which is one of the tools of the state to ensure the welfare of the people, including the realm of the natural resource management. However, sectoral dualism makes SOEs trapped in the demands for profit-oriented obligations and subject to the Limited Liability Company Law (UU PT). This is a problem in the management of natural resources by SOEs. SOEs are trapped in the political intervention, individuals who take advantage of this situation and as a result, the main task of SOEs as public services cannot be optimal. This study was done using a normative research with primary and secondary legal materials, analyzed deductively with a statutory and philosophical-conceptual approach. The results of the study indicate: (i) the urgency of establishing good corporate governance in overcoming the sectoral dualism of BUMN (State Owned Enterprises) are: a. SOEs do not yet have the stability of functions and objectives, $b$. BUMN management is still filled with the government intervention; (ii) the optimization of natural resource management based on good corporate governance by BUMN are: a. internalization of the principles of accountability and professionalism, c. build a healthy partnership pattern between the government and SOEs.
\end{abstract}

Keywords- BUMN, Good Corporate Governance, Management.

\section{INTRODUCTION}

In Indonesia, the duality position in the public service, where there is a relationship between a political party and state-owned enterprises, is always controversial. The problem of dualism of State-Owned Enterprises (SOEs/BUMN) is an obstacle that hinders the efforts to realize the optimization and professionalism of the natural resource management. This dualism refers to the regulation of BUMN in Law Number 19 of 2003 concerning BUMN (BUMN Law) and Law Number 40 of 2007 concerning Limited Liability Companies (UU PT). This encourages the business activities of SOEs to be more or less influenced by the government policies due to this sectoral dualism. BUMN, State-owned enterprises (SOEs) are wholly or majority government-owned companies that engage in extractive activities on behalf of the state. A state-owned enterprise (SOE) is a legal entity that is created by a government in order to partake in commercial activities on the government's behalf. It can be either wholly or partially owned by a government and is typically earmarked to participate in specific commercial activities. BUMN is one of the implementing agencies for the economic activities of a country which is formed based on the law. The state actually requires SOEs to carry out business activities, one of the results of which is to fund various interests and needs of the state. Usually in every independent country, the role of economic activity is taken by BUMN and BUMS (Private Owned Enterprises). SOEs have played a very important role in the development and economy of the country long since Indonesia proclaimed independence until now. The state carries out economic activities in the form of companies in the context of implementing Article 33 of the 1945 Constitution of the Republic of Indonesia [1].

The wealth of BUMN is regulated in Article 2 letter $g$ of the BUMN Law, namely: "State assets/regional assets managed by themselves or by other parties in the form of money, securities, goods receivables, and other rights that can be valued in money, including assets separated on state company or regional company." Therefore, literally, BUMN losses are state losses, considering that BUMN assets are classified as state assets from their capital participation. Furthermore, when referring to the form of BUMN Persero, which is vaguely subject to the Limited Liability Company Law, in fact a wider responsibility can be drawn since all actions of the company, good and bad, are borne by the company [2]. Article 11 of Law Number 19 of 2003 concerning BUMN stipulates that in terms of carrying out the management of BUMN, the provisions and principles in Law Number 40 of 2007 concerning PT. The implication is that the provisions and principles that apply to PT will be attached to SOEs, such as the separation of wealth between the founders and management of the company.

However, what needs to be understood is that capital participation from the State Revenue and Expenditure Budget (APBN) is actually the legitimacy of the people to the state through SOEs so that there will be output from SOEs that are useful for the people. The intended use is specifically in terms of public services and other things that support the welfare of the people. Therefore, in the event of a loss in running a BUMN Persero, even though 
the BUMN is subject to the provisions of the Limited Liability Company Law, it cannot be separated from the state losses. This happens since the SOE's capital is separated from the state assets, even though it places the state as a shareholder, in practice, the state still determines the direction of SOE's policies and business activities. One of the proofs is that the Ministry of SOEs exists and toward it, the President can carry out assignments through the Presidential Regulations and other legal products. Therefore, in this position, SOEs do not only carry out capital separated from the state, but also as a tool of the state in their policies. Therefore, it is not impossible that in the future there will be a breakthrough in the form of valuation of BUMN losses which are classified as state losses due to the participation of the government in determining the policy directions and even taking forms of intervention on BUMN business activities.

Ideally, the management of SOEs should be carried out independently, professionally and free from the intervention of its shareholders, including the state as the shareholder and controller. State control does not necessarily to be separated, since BUMN, in this case also has a public service goal. SOEs have historically been born due to the inability or limitations of the state in providing guarantees for the needs of the people. Therefore, aside of being profit oriented (a statement in the BUMN Law and the PT Law), BUMN are also still controlled by the state, particularly in the implementation of public services [3].

\section{RESEARCH METHOD}

Based on its approach and nature, this article is classified as normative legal research. This study was prepared by using primary and secondary legal materials, and analyzed deductively by using a statutory approach and by using a philosophical-conceptual approach. This study was conducted with the aim of showing a prescriptive on everything that should be applicable to the legal issues under study.

\section{FINDINGS AND DISCUSSION}

\section{The Urgency to Establish Good Corporate Governance in Overcoming State Owned Enterprises Sectoral Dualism}

First, BUMN/SOEs do not have stability of functions and goals. Functional stability relates to the consistency and commonality of perception which of course is found to be consensual in the substance of the BUMN regulation. However, in fact, this has not been discovered by the writer who actually found the dualism of the function and purpose of SOEs. This includes the realm of natural resource management as regulated in the Article 33 of the 1945 Constitution of the Republic of Indonesia with the proportion of dualism in the form of dominant government participation so that it becomes a BUMN policy maker in the natural resource management.

The dualism of the SOE's function is burdened with the public service obligations as well as profit seeking which in this case includes the realm of the natural resource management as an important object for the livelihood of many people. Based on the principle, the management of natural resources is the fulfillment of the wishes and needs of the community by the state administrators. In essence, the state through the government in carrying out its executive functions is required to meet the needs of the community, including the distribution of natural resources [4]. Moenir is even more specific about the needs of the community which in this case are not only individual needs but also include the real needs that are the expectations of the community, such as the need for health, education, and the needs that support the community productivity such as transportation, electricity, fuel oil, fertilizers and seeds for farmers [5]. Thus, it is necessary to reconsider giving SOEs the burden of being obliged to carry out the public services while seeking profit if they are still fulfilled with the government intervention through their policies. Causality, with the government policy intervention in the form of assignments, it is often found cases of SOEs becoming losers due to assignments that are not on target, paying less attention to SOE profits so that SOEs lose. The loss of SOEs means that the management of the natural resources is hampered which affects the distribution of benefits to the community.

The distribution of the natural resources actually shows how the role of the government is to be able to connect with the citizens through the benefits derived from the management and distribution of these natural resources. Polls show public confidence in the government institutions in managing natural resources that has declined and the public still believes that the government programs for it are not responsive enough. Responsive management and the distribution of the natural resources, ideally, should legitimize the stability of the function and purpose of BUMN to manage it through the existing bureaucratic structure, reformers have tried to place citizens (as beneficiaries of the distribution of natural resources) as a parameter of the success of the country in realizing prosperity. The presence and activities of SOEs have not been supported by a clear classification of types of objectives, so that this makes the activities of SOEs inconsistent, prone to the structural policy intervention, causing losses. Study conducted by Ansari [4] concluded that the Government's assignment needs to be adjusted to the corporate law, namely taking into account the aims and objectives of the BUMN entity. This happens since each BUMN entity has its own aims and objectives as regulated in the legislation. Statistics show that the losses experienced by SOEs are quite significant quantitatively. Data for 2018 shows the number of SOEs that have lost 24 SOEs or about 20 
percent of the total 118 SOEs that are active in Indonesia. Although, quantitatively, the number of state-owned enterprises that lost is less than the data summarized in 2013 where there were around 30 state-owned enterprises that lost, but the amount of loss was large with a total loss of Rp. 32.6 trillion [6].

In general, there are two notions about public service: (i) which is based on the principle of the welfare state; (ii) who considers public service as an attempt to make a profit [7]. The difference in understanding is about how the state and efforts to position itself in the public service scheme (public service). In the concept of the welfare state, it is clear that public services are carried out by the state, both public institutions/agencies by using the State Budget (APBN) and/or Regional Budget (APBD). BUMN such as PT must carry out both as Corporate and Public Service [8]. After the enactment of Law Number 19 of 2003 concerning BUMN, it is actually necessary to harmonize regulations in strengthening the form and aligning the functions and objectives of BUMN. This can be started from harmonization of government regulations which include: (i) Government Regulation Number 33 of 2005 concerning Procedures for the Privatization of Companies (Persero), which is a policy on the privatization of BUMN; (ii) Government Regulation Number 43 of 2005 concerning Merger, Consolidation, Acquisition and Change of Legal Entities; (iii) Government Regulation Number 44 of 2005 concerning Procedures for State Equity Participation and Administration in BUMN and Limited Liability Companies (PT); and (iv) Government Regulation Number Year 2009 concerning Amendments to Government Regulation No. 33 of 2005 concerning Procedures for the Privatization of Limited Liability Companies (Persero), in which the Government establishes a policy on the privatization of SOEs.

The conclusion that can be seen is that BUMN sectoral dualism leads to two main things as summarized by the writer, namely: (i) BUMN capital comes from the separated state assets, but the state does not only act as a shareholder as stipulated in the Limited Liability Company Law, but, in the practice, the state determine many directions and policies and/or business activities of SOEs; and (ii) the involvement of the state in determining the direction of policies and/or business activities of SOEs makes SOE directors cannot be equated with directors or directors of companies in general as stipulated in UU PT. Thus, the responsibilities of SOE directors are significantly different from the responsibilities of company directors in general. Therefore, the role of the state in the management of SOEs is the cause of the sectoral dualism, since, SOEs at this point are not absolutely subject to the provisions of UU PT, but there is still government participation in determining the direction of their business activities. In fact, in some cases, there are two-sided government actions against SOEs. As a result, the government's two-sided actions (civil acts/materialelle daad), are not fully subject to the rules of civil law, and are even followed by unbalanced substance. Thus, it is necessary to resolve the problem of SOE sectoral dualism as the first step in constructing an accountable and professional SOE.

Second, owned enterprises management is still fulfilled with government intervention. De Shutter [9] explains that: "...the welfare state is not only a mechanism to intervene toward, or correct the existing structures of inequality. However, it is a distinctive system of social stratification. The welfare state is a dynamic force in the realignment of social relations [23] [4]. Relevant to the Pancasila economic development paradigm in the form of a populist economic system based on kinship. The goal is to inspire, reflect and implement the values of Pancasila which should animate as a spirit in the legal products of this country as a legal ideology. [20] The 1945 Constitution of the Republic of Indonesia regulates the provisions of the Indonesian economy in Article 33 with the link between the economy and welfare which is a direct mandate of the Preamble or Preamble to the 1945 Constitution of the Republic of Indonesia. Therefore, efforts to implement the Article 33 The 1945 Constitution of the Republic of Indonesia can be called an effort to realize an economic constitution [10]. The economic constitution is the embodiment of the embryonic basic conception of the direction of the Indonesian economy which is based on the sovereignty of the people. The state is the motor of implementing the sovereignty of the people which is distributed to the state. This implementation is manifested in the regulations and policies to achieve the final result, namely the welfare of the community which is returned to the people [11].

The principle of the sovereignty of the people is the basic idea about the composition of the state, which is essentially a concept of the state, which will be the basis for the growth of the content and direction of the next rule of state law. Marliam Simanjuntak emphasized that the concept of the state (staatsidee) is an earlier source of the framework drawn up in a constitution [12]. The concept of this state on the one hand will have consequences on the constitutional law and the state life or the state administration practices in general. The above is the main door to criticize the intervention of government on BUMN (SOE), particularly in the optimization and professionalism of the natural resource management, where many cases are found. Thus, it is not justified to intervene through government policies that can disrupt the performance of SOEs. The government is required to be able to develop a good and balanced pattern of cooperation with state companies (BUMN). It is expected that the implementation of the competitive model pattern can create beneficial implications for the state, SOEs and especially the community through the satisfying performance of SOEs in carrying out the public services. Therefore, there must be a non-intervention consensus that is needed as a guarantee that the state does not 
interfere through doctrinalization or pressures or negative political will including various spoil systems against the interests of SOEs that are obliged to optimize and professionalize the natural resource management for the benefit of the state people.

Therefore, to be able to guarantee and provide a legal basis, that the government's actions (bestuurhendeling) as a legal act (legitimate and justified), accountable and responsible, then every act of the government must based on fair, dignified and democratic [13]. The realization of non-intervention is still far away since in the practice, there are many interventions to SOEs by the government through its policies, even at the level of two-sided actions (materialele daad) where in fact the government in carrying out civil actions must comply with the rules of civil law. However, this is deviated by the Government by intervening in the form of SOEs. This is not healthy, particularly for the development and growth of SOEs. The principle of non-intervention is also one of the realizations of the fulfillment of the principle of fair play or a decent game or the principle of a fair game as one of the General Principles of Good Governance (AUPB). This can be observed by considering the position of government which cannot be separated from the function of public services. The management of SOEs has not been carried out in a professional manner by fully complying with UU PT. Therefore, to avoid the government intervention due to the intersection and mixing of the functions of the management of SOEs, the principle of non-intervention must be included with the safety net of the principle of feasible play or fair play or the principle of fair play.

\section{Optimization of the Natural Resources Management Based on Good Corporate Governance by State Owned Enterprises}

First, of the principles of accountability and professionalism. The principle of good corporate governance is a bridge as well as a reference in efforts to optimize the management of natural resources by SOEs. The bridge concerned can be started by reflecting on the internalization of the principles of good corporate governance, particularly the principles of accountability and professionalism. This is an answer to the problem of BUMN sectoral dualism which leads to the incompetence or inability of BUMN to manifest accountability and professionalism in the manifestation of their business activities. Thus, the writer presents improvements, particularly in terms of accountability and professionalism in managing the natural resources by SOEs by internalizing the principles of accountability and professionalism. Internalization of the principle of accountability as a way to re-enforce the accountability mechanism of BUMN (SOE), particularly if there is a loss to the management of natural resources whose benefits must be distributed to the people. On this principle, SOEs in managing the natural resources must be able to account for their performance in a transparent and fair manner. This is the first step to facilitate the distribution of the benefits of these natural resources to the community. On this principle, in the management of natural resources, SOEs must be able to account for their performance in a transparent and fair manner. This is the first step to facilitate the distribution of the benefits of these natural resources to the community. Internalization of the principle of professionalism as a way to maintain the performance of SOEs, particularly in the management of natural resources, to remain sustainable towards a better direction in line with the ideals of realizing good corporate management. BUMN as a company is required to uphold the principle of professionalism. Therefore, the literature presents an interesting implication, that if SOEs are still not free from the government intervention, the professionalism concerned will still fail and will only be under the shadow of the government policy. Such a position makes it difficult for SOEs to be able to move and develop in order to advance their business activities, including in the management and distribution of the natural resources [14]. Its relevance to the current conditions of globalization, increasingly puts demands on SOEs to synergize and adapt to the global developments which of course require creativity in the development of business activities. However, the fact that government intervention is still the main obstacle for SOEs towards the direction of improvement and development concerned.

Second, build a healthy partnership pattern between the government and BUMN/SOEs. Optimizing the management of natural resources based on good corporate governance by SOEs can be actualized by building a partnership pattern between the government and SOEs. This step is a middle way towards the creation of optimization and professionalism of the natural resource management by BUMN considering the urgency and vital value of management along with the distribution of the benefits of these natural resources to the community in order to support the realization of the welfare of the people. Lazer [15] offers three models of interdependence regulation, namely: (i) competitive model; (ii) coordinating model; and (iii) coordinative hegemony model. The main assumption of the interdependence competition regulation model is that policy performance is determined by the intersection of interests between companies. The government then makes this meeting point the basis for regulations that are generally accepted by the community. This practice is often heard to the public regarding fair competition and anti-monopoly policies. However, some people think this method is not good administratively.

Competitive model is characterized by competition between private and state-owned companies. In the classic business tradition, the way to overcome unfair competition is to create a good pattern of cooperation. However, in this modern era, the model of cooperation is increasingly unused in the modern business, some of the 
businessmen actually choose to develop production and market cartels. Thus, what was originally possible in the form of cooperation, has now been subtly monopolized in the cartel management pattern [16]. The state's attitude towards this aspect shows a strong administrative side, there are at least two government policy externalizations, namely: (i) the state tries to gain competitive advantage by accommodating the best competitors as an image for the state's production standards; and (ii) through the results of the first point, the Government creates conditions that allow small competitors who do not have the power to reap the rights to the quality. This section occurs a lot in the realm of Intellectual Property Rights such as trademark administration, copyrights and patents [17]. This condition is the one that dominates the relations between countries in Europe and America with their public companies for the sake of the country's economic interests.

Coordinative model of cooperation, it is possible to do, the administration of an import destination country, incidentally is formed from the cooperation with their best partner countries. The administrative speculation is carried out with full calculation of the economic path opportunities that allow the country to grow on the support and use of other countries. Therefore, from the beginning, business administrations between countries and or between companies were preceded by research that accommodated the wishes of partners, the public and or consumers. In trade relations between countries, the partners and consumers are countries [18]. This coordinating model allows the state to work with its best partners which also opens up positive competition between public and private companies. It is expected to create healthy competition and improve the quality of public companies, in this case BUMN, including in terms of the natural resource management.

Coordinative hegemony model, it forms a pattern of domination over countries with lower-middle economies of scale. This situation seems to get legitimacy in today's era of economic globalization. Economic globalization is a macro force whose impact is felt by almost every country. Economic globalization can create a network of market power which, if not anticipated with preparation and regulated, will undoubtedly be controlled by certain countries that are strong in terms of capital, resources, relations and innovation. This situation can create a dominant position in business activities, consequently creating an unhealthy monopoly practice that can harm other parties in business activities. Dominant position is a situation where a business actor has no significant competitors in the relevant market with respect to the market share the business actor controls, or a business actor has the highest position among its competitors in the relevant market in terms of financial capability, ability to access supply or sales, and the ability to adjust supply or demand for certain goods or services [19]. Thus, from the three models above, parameters can be arranged in building a healthy partnership pattern between the government and BUMN/SOEs. This goal is in accordance with the constitution, namely the welfare of the people [21] [22].

\section{IV.CONCLUSION}

The conclusion of this article shows that the urgency of establishing good corporate governance in overcoming the sectoral dualism of SOEs is motivated by the arguments described from various factual cases that stateowned enterprises do not yet have stability in functions and objectives and the management of SOEs is still fulfilled with the government intervention. Meanwhile, optimizing the management of natural resources with SOEs based on good corporate governance can be done by internalizing the principles of accountability and professionalism and building a healthy partnership between the government and SOEs

\section{REFERENCES}

[1] Moch. Faisal Salam, Empowerment of SOEs in Indonesia, Bandung, Pustaka, 2005

[2] Rudy Prasetya, Independent Limited Liability Company, Bandung, Citra Aditya Bakti, 1995.

[3] Aminuddin Ilmar, The Right to Control the State: In the Privatization of BUMN, Jakarta, Kencana, 2012.

[4] Muhammad Insa Ansari "State-Owned Enterprises and Public Service Obligations in the Postal Sector," Journal of Postal and Informatics Research, vol. 8, no. 1, pp: 1-18, September 2018.

[5] H. A. S, Moenier, Public Service Management in Indonesia, Jakarta, Bumi Aksara, 2002.

[6] Kompasiana,https://www.kompasiana.com/nadbas_679/5b570e6b caf7db7fc7704052/benarkah-bumn-kita-terus-merugi?page=all

[7] Nikmah, et. al., "My Train Loves My Poor Train: Railway Efficiency Project,"'Working Paper in International NGO Forum on Indonesia Development (INFID), Jakarta, No. 1, 2008.

[8] Sudibya, Fair Railroad Governance, Depok, Rajawali Press, 2019.

[9] Olivier De Schutter, "Welfare State Reform and Social Rights," Netherlands Quarterly of Human Rights, vol. 33, no. 2, pp: 39-49, 2015.

[10] Jimly Asshiddiqie, Economic Constitution, Jakarta, Kompas, 2010

[11] Isharyanto, Constitution and Constitutional Amendments, (Study on the Effects of Amendments to the Basic Law in the Administration of the State), Surakarta, Pustaka Hanif, 2016.

[12] Marliam Simanjuntak, Integralistic State View: Sources, Elements and History in the Preparation of the 1945 Constitution, Jakarta, Pustaka Utama Grafiti, 1994.

[13] Mulhadi, Company Law: Forms of Business Entity in Indonesia, Bogor, Ghalia Indonesia, 2010.

[14] Sri Hermuningsih, "The Effect of Profitability, Growth Opportunity, Capital Structure on Firm Value in Public Companies in Indonesia," Bulletin of Monetary, Economics and Banking, 2013.

[15] David Lazer, "Global and Domestic Governance: Modes of Interdependence in Regulatory Policy Making," European Law Journal, vol. 12, no. 4, pp: 455-468, July 2006.

[16] David Lazer, "Regulatory Interdependence and International Governance," Journal of European Public Policy, vol. 1, no. 1, pp: 474-490, April 2001.

[17] David Lazer and A. Friedman, "The Parable of the Hare and the Tortoise: Small Worlds, Diversity, and System Performance," KSG Faculty Research Working Paper Series RWP05-058, October 2005 
[18] David Lazer and V. Mayer-Schoenberger, "Governing Networks," Brooklyn Journal of International Law, vol. 27, no. 3, pp: 819-851, 2002.

[19] Vegitya R. Putri, Business Law, Malang, Setara Press, 2013.

[20] David Nelken David Nelken, "Is There a Crisis in Law and Legal Ideology?", Journal of Law \& Society, vol. 9, no .2, pp: 177-183, 1982.

[21] Ainur Rofieq, "Pelayanan Publik dan Welfare State", Governance, vol. 2, no. 1, 2011.

[22] Oman Sukmana, "Konsep dan Desain Negara Kesejahteraan (Welfare State)", Sospol, vol. 2, no. 1, pp: 98-105, 2016.

[23] Brigitte Unger, Karin Hietzmann, "The Adjustment Path of the Austrian Welfare State: Back to Bismarck?", Journal of European Social Policy, vol. 13, no. 4, pp: 371-388, 2003.

[24] John Myles, Jill Quadagno, "Political Theories of the Welfare State", Social Service Review, vol. 76, no. 1, 75th Anniversary Issue, pp: 34-57, March 2002. 